\title{
Audiological Investigation of Otitis Media in Children with Atopy
}

\author{
Francesco Martines • Daniela Bentivegna
}

Published online: 5 October 2011

(C) Springer Science+Business Media, LLC 2011

\begin{abstract}
Otitis media (OM) describes an inflammatory process within the middle ear space that is generally associated with accumulation of fluid and that may lead to hearing loss, learning difficulties, and delays in language development. The pathogenesis of $\mathrm{OM}$ is multifactorial, involving the adaptive and native immune system, eustachian tube dysfunction, viral and bacterial load, and genetic and environmental factors. The involvement of IgEmediated allergic reactions in the pathogenesis of OM has been suggested by clinical observations of a high prevalence of OM among patients with allergies. Evidence from studies involving tympanometric measurements, audiometric measurements, and otoscopic examination confirms the role of atopy in the development and persistence of OM.
\end{abstract}

Keywords Otitis media $\cdot$ Middle ear effusion $\cdot$ Acute otitis media $\cdot$ AOM - Children - Otitis media with effusion - OME . Allergy · Auditory tube dysfunction · Otitis · Audiological . Atopy

F. Martines $(\bowtie)$

Sezione di Otorinolaringoiatria, Dipartimento di Biomedicina

Sperimentale e Neuroscienze Cliniche, (BioNeC),

Università degli Studi di Palermo,

Via del Vespro,

129-90127 Palermo, Italy

e-mail: francesco.martines@unipa.it

D. Bentivegna

Sezione di Audiologia, Dipartimento di Biopatologia e

Biotecnologie Mediche e Forenzi (Di.Bi.Me.F.),

Università degli Studi di Palermo,

Via del Vespro,

129-90127 Palermo, Italy

\section{Introduction}

Otitis media (OM) describes an inflammatory process within the middle ear space that is generally associated with accumulation of fluid that results in decreased mobility of the tympanic membrane and a conductive type of hearing loss. It continues to be one of the most common health problems seen in children. When inadequately treated or left untreated, it may lead to sequelae and complications consisting of retraction pockets, tympanosclerosis, adhesive otitis media, permanent hearing loss, and impairment in development of speech and language [1-4].

Two forms are recognized: acute otitis media (AOM) and otitis media with effusion (OME). AOM is defined as the presence of middle ear effusion (MEE) in conjunction with the rapid onset of one or more signs or symptoms of inflammation in the middle ear, such as otalgia, otorrhea, fever, or irritability. OME is defined as MEE without signs or symptoms of an acute infection; it may occur de novo or as a sequel to $\mathrm{AOM}$ [5]. Therefore, $\mathrm{AOM}$ and $\mathrm{OME}$ represent different stages of the OM continuum.

\section{Advances in Epidemiology}

An overview of published articles reveals considerable variation in prevalence rates among the worldwide $\mathrm{OM}$ reports, depending on the methods used and population characteristics. It is recognized that most children have at least one episode of MEE (includes AOM and OME) in their life, but the lack of acute symptoms with OME makes OM prevalence difficult to estimate. In the first year of life, more than $50 \%$ of children will experience OME, and the percentage increases to greater than $60 \%$ by age 2 years. Many episodes resolve spontaneously within 3 months, but 
about $30 \%$ to $40 \%$ of children have recurrent OME, and $5 \%$ to $10 \%$ of episodes last 1 year or longer [6-8]. Reviewing some articles about the issue, Zielhuis et al. [9] used the age-specific prevalence rate and came to the conclusion that the rate has two peaks: one at about 2 years of age, probably leading to immaturity of function of the immune system and to anatomic and functional diversity of the eustachian tube (ie, nearly horizontal orientation), and the other at about 5 years of age, probably because children attend the same classes at school, with consequent increased susceptibility to infectious and allergic agents. With increasing age, the prevalence rate of MEE decreased. The reported prevalence rates of OM among primary school children in the literature are $10.4 \%$ in a study from Turkey including 912 children between 6 and 8 years of age [10], $6.8 \%$ in Italy $(2,132$ children, $5-14$ years old $)[11 \cdot], 9.5 \%$ in The Netherlands (1,004 children, 5-8 years old) [12], 13.8\% in Saudi Arabia (4,124 children, 1-8 years old) [13], and $6.5 \%$ in Greece $(5,121$ children, $6-12$ years old) [14].

\section{Advances in Pathogenesis}

The panel report from the Ninth International Research Conference on Otitis Media suggests that the etiology of $\mathrm{OM}$ is multifactorial, as many different factors are implicated in the pathophysiology of this disease [15••]. OM is mainly an infectious disease resulting from interplay between microbial load (viral and bacterial) and immune response, and it is clearly related to dysfunction of the eustachian tube. All factors known to cause OM relate to these two core elements: host factors such as age, genetic predisposition, and atopy relate to the impaired immune system, whereas environmental factors such as bottle feeding, mother's working, group day care attendance, and season of year relate to microbial load [5].

For many years, physical obstruction of the eustachian tube was thought to produce MEE because of negative middle ear pressure and fluid transudation (ex vacuo theory). Presently, more complex theories describe the crucial role of the eustachian tube in maintaining a healthy middle ear via equilibration of pressure between the middle ear and ambient air (ventilatory function), protection against nasopharyngeal pressure variations and ascending secretions or pathogens (protective function), and clearance of secretions and debris toward the nasopharynx (clearance function) $[16,17]$. Therefore, the dysfunction can be caused by extrinsic factors, such as upper respiratory tracts infections (URTIs), adenoid hypertrophy, chronic sinusitis, or rhinitis, or by intrinsic factors, such as infection or allergy, that are common diseases among primary school children. Moreover, infants and young children are vulnerable to OM because their eustachian tubes are short, floppy, and horizontal, and they function poorly. If sustained, the dysfunction might be followed by aspiration of potential pathogens (viruses and bacteria) from the nasopharynx to the middle ear. Streptococcus pneumoniae, Moraxella catarrhalis, nontypeable Haemophilus influenzae, and respiratory syncytial virus or rhinovirus are the predominant pathogens that cause OME. Pathogens or by-products stimulate local resident cells, attracting immune-effector cells and provoking the inflammatory response largely responsible for clinical manifestations [18].

\section{Role of Atopy}

Recent guidelines from otologists, pediatricians, and allergists based on clinical evidence support the role of atopy in the development and persistence of OM $[11 \bullet, 15 \bullet \cdot]$. Atopy had been defined by the European Academy of Allergy and Clinical Immunology Nomenclature Task Force as a personal or familial tendency to produce $\operatorname{IgE}$ antibodies in response to low doses of allergens, usually proteins. It is the genetic predisposition, transmitted as a dominant factor, to become allergic to a definite number of specific allergens [19]. Approximately $20 \%$ to $30 \%$ of the general population and $10 \%$ to $15 \%$ of children are atopic [20].

In 1931, Proets [21] was the first to note a relationship between patients with allergic rhinitis (AR) and OM, and Koch [22] was the first to include observations of eosinophilia in otorrhea, supporting the contention that the middle ear takes part in allergic reactions similar to those seen in the nose and sinuses. In 1967, Shambaugh [23] described middle ear inflammation associated with allergic diseases as "allergic otitis media." He mentioned that one of the criteria for the diagnosis was the presence of an extremely viscous mucoid effusion containing eosinophils [23]. Recently, other investigators have reported that the composition of the inflammatory substrate in MEE is similar to the late-phase allergic response seen in other areas of the respiratory tract, such as in chronic sinusitis, AR, and asthma. Wright et al. [24] demonstrated an increased expression of interleukin (IL)-5 and eosinophils in the middle ear mucosa of patients with OM. Hurst and Venge [25] reported elevated levels of eosinophil cationic protein in MEE. Also, Nagamine et al. [26] observed the accumulation of eosinophils and eosinophil cationic protein in MEE. Jang and Kim [27] found significantly higher levels of allergic mediators such as IL-4, IL-6, and tumor necrosis factor- $\alpha$ in the MEE of the allergic individuals suffering from OM. Sobol et al. [28] also found that atopic patients have a significantly higher percentage of 
T lymphocytes, eosinophils, mast cells, basophils, IL-4, and IL-5 in MEE, and Hurst and Venge [25] reported that mast cells and the mediator tryptase are present in the majority of ears that have chronic effusion. Overall, these results support the hypothesis that the immunopathologic mechanism underlying the development of MEE can be largely a result of the effects of T-helper type 2 (Th2) mediators; thus, the inflammation within the middle ear of many patients is allergic in nature. In contrast to atopic patients, nonatopic patients revealed different cellular and cytokine profiles in the MEE and nasopharynx, with a predominantly Th1mediated inflammatory response [29].

Allergy may be related to OM etiology through different mechanisms. Experiments indicated that the middle ear mucosa is capable of sustaining an allergic reaction; however, the extent and duration of inflammation were limited, and OME was not observed. It is now well-known that the nose and middle ear are not independent entities, but rather they belong to a system of contiguous organs, including the nose, eustachian tube, palate, nasopharynx, middle ear, and mastoid cells - the so-called rhinopharyngotubal unit. Basically, nasal allergic inflammation leads to swelling and obstruction of the eustachian tube, which in turn determines a negative pressure in the middle ear and an improper ventilation. In this context, a transient eustachian tube opening results in aspiration into the middle ear cavity of nasopharyngeal secretions containing bacteria and viruses with the obvious physiopathological consequences [30•]. Moreover, several studies revealed the presence of very similar cellular and cytokine profiles in adenoid tissue, showing that adenoids also may represent a potential site of allergic inflammation. Adenoid inflammation with concomitant hypertrophy has long been recognized as the most common cause of eustachian tube dysfunction in children and, thus, of OM [31••, 32]. Reviewing the literature, we found that many epidemiologic studies were conducted to support the existence of a relationship between $\mathrm{OM}$ and atopic disease. Using objective intradermal and in vitro testing, many investigators have demonstrated a high prevalence of OME among atopic patients: Dohlman (56\%) [33], Mao (29\%) [34], Jordan (74\%) [35], Solow (72\%) [36], Lecks (88\%) [37], Fernandez and McGovern (55\%) [38], Whitcomb (100\%) [39], Draper (53\%) [40], Hall et al. (100\%) [41], McMahan et al. (93\%) [42], Modrzyński et al. (72\%) [43], Hurst and Venge (100\%) [25], Nsouli et al. (78\%) [44], Yeo et al. (28\%) [45], Hurst et al. (81\%) [46], Sobol et al. (30\%) [28], Alles et al. (94\%) [47], and Martines et al. $(28.04 \%)[48 \cdot 0]$. In our study, conducted in children 5 to 6 years of age, $60 \%$ of those with OME were atopic, while $40 \%$ were nonatopic. A total of $42.85 \%$ of the atopic population was found to suffer from OME, while the percentage with OME among nonatopic individuals was $6.29 \%[49 \bullet \cdot$.

\section{Advances in Audiological Diagnosis}

The diagnosis of middle ear pathology, especially in children, can be difficult. MEE is a prerequisite for AOM and OME. Many diagnostic procedures are used to detect MEE, including use of pneumatic otoscopy, tympanometry, and acoustic reflectometry.

Pneumatic otoscopy is the primary diagnostic method for $\mathrm{OM}$ recommended by the guidelines of the American Academy of Otolaryngology Head and Neck Surgery [50]. It provides detailed information about the change in the tympanic membrane and the middle ear. The main features in diagnostic assessment of the tympanic membrane in OM were classified by Kaleida and Fireman [51] into color, mobility, translucency, fluid appearance, and retraction. Tympanic membrane findings that are suggestive of $\mathrm{OM}$ are color other than pearly gray, opacification of tympanic membrane, fluid level, decreased mobility, and retracted position [51]. These findings are to be combined with a clinical history to differentiate OME from AOM. Acute symptoms in AOM may include earache, tugging or rubbing of the ear, irritability, restless sleep, and fever.

Tympanometry is a simple and objective method that assesses transmission and pressure system integrity of the middle ear; it also measures auditory canal volume and eustachian tube function by introducing air under pressure. The tympanographic trace was classified according to basic curve types described by Liden and Jerger: type A, normal eustachian tube function; type $\mathrm{B}$, flat tympanogram characteristic of the presence of fluid in middle ear; and type C, characterized by peaks at very negative pressures (typically -150 decaPascal [daPa]) and may be indicative of eardrum reaction.

Audiometry can be used to confirm the diagnosis of OM. Conductive hearing loss is a common sequelae of OM due to the attenuation of sound reaching the inner ear by MEE. Audiometric threshold is considered as the pure tone average for the frequencies 0.5 to 1 to 2 to 4 to $8 \mathrm{kHz}$ and divided as follows: normal hearing $(<20 \mathrm{~dB})$, light hearing loss (21-40 dB), moderate hearing loss (41-70 dB), severe hearing loss (71-90 dB), and profound hearing loss ( $>90 \mathrm{~dB})$. The report of the Eighth Research Conference of Otitis Media stated that children with bilateral MEE had hearing levels 10 to $16 \mathrm{~dB}$ worse than those of children without MEE in all age groups. Hearing levels in children with $\mathrm{OM}$ usually range from 10 to $40 \mathrm{~dB}$, depending on character and quantity of effusion [52]. Fria et al. [53] 
reported an average air conduction threshold of $27 \mathrm{~dB}$ in 540 children 2 to 12 years old with OME, while Ungkanont et al. [54•] reported $31.7 \mathrm{~dB}$.

\section{Audiological Findings in Atopic Children}

As stated previously, data in the literature support the hypothesis that allergic inflammation may have a role in the genesis and recurrence of OM. Certainly, atopy is recognized as a risk factor; therefore, many epidemiologic studies were performed to assess whether audiological measurements in atopic individuals suffering from $\mathrm{OM}$ are significantly different compared with those of nonatopic individuals (Table 1).

\section{Tympanometric Measurements}

In 2005, considering the impact of chronic middle ear disease regardless of age, Lazo-Saenz et al. [55] conducted a study to assess eustachian tube function using tympanometry in individuals with $\mathrm{AR}$ and to compare them with healthy individuals with the aim of exploring the magnitude of OM diseases in an at-risk population such as those with allergies. The tympanometric measurements indicated that children and adults with AR had more negative values of tympanometric peak pressure (TPP) than controls $(P \leq 0.05)$, but the main finding of tympanometry resulted among the children with AR who were younger than 11 years of age. In fact, it was shown that negative values of TPP and abnormal curves were present in $15.5 \%$ of children $(13 \% \mathrm{C}$ curves, $3 \% \mathrm{~B}$ curves), while only A curves were found in the control group $(P=0.03)$ [55]. Also, Yeo et al. [45] investigated the role of atopy in the development of OME and its effect on eustachian tube function after nasal provocation tests by tympanometric measurements. A total of 142 children, ranging in age from 9 months to 12 years, treated in the department of ear, nose, and throat from September 2004 to February 2006, with no history of OME or ear symptoms, were divided into an AR group and a control group ( $n=63$ and 79 participants, respectively). The AR group consisted of children who had symptoms such as sneezing, watery rhinorrhea, nasal obstruction, and pale or watery nasal mucosae as detected by physical examination, and a positive reaction to house dust, Dermatophagoides farinae, or cockroach mix in allergy skin reaction tests. Of the 63 patients in the AR group in whom the authors performed nasal provocation tests, $6.3 \%$ were found to be type B or C by tympanometry, compared with $3.8 \%$ in the control group [45].

Three years earlier, another study in humans tried to establish a retrospective causal linkage by studying patients with chronic $\mathrm{OM}$ to determine the history of allergic background. In this study, Sente et al. [56] concluded that $25 \%$ of participants overall (200 patients aged 5-19 years), $80 \%$ of whom ranged in age from 5 to 9 years, with diagnosed eustachian tube dysfunction also suffered from AR. Moreover, the tympanometric results showed a significant difference between $\mathrm{B}$ and $\mathrm{C}$ curves $(86.5 \%$ and $13.5 \%$, respectively, for $B$ and $C$ type) [56].

Leo et al. [57] recently evaluated the prevalence of middle ear dysfunction, as assessed by tympanometry, in children 1 to 14 years of age with chronic sinusitis among a large group of patients with chronic respiratory symptoms, and its possible relationship with respiratory allergy. From a population of 1,810 children, $288(15.9 \%)$ had a clinical diagnosis of chronic sinusitis; of these, altered pressure of the middle ear was found in $76.4 \%$, with a significantly higher prevalence among the younger children $(P<0.001)$. This seems to confirm that URTI is one of the predisposing factors to OM development; moreover, the authors showed that a positive reaction to skin prick test was found in 86 children $(29.9 \%)$, with a prevalence of positivity significantly different among various age groups $(P=0.01)$. In particular, the percentage values, $31.8 \%$ for children aged 3 to 6 years and $34.1 \%$ for those older than 6 years of age, were higher than those of the healthy population $(10 \%-$ $15 \%$ ). Among atopic individuals, $26.7 \%$ were type C tympanogram, while $43 \%$ were type B. Altered tympanogram was observed in $100 \%$ of atopic children younger than 3 years of age, in $74.3 \%$ aged 3 to 6 years, and in $46.7 \%$ older than 6 years of age. The results demonstrate that eustachian tube dysfunction is very common in children with chronic sinusitis, but the dysfunction significantly decreases in frequency with age, showing a rate of $87.5 \%$ in children younger than 3 years of age, of $79.6 \%$ in those 3 to 6 years of age, and in $54.5 \%$ of those older than 6 years of age. The anatomic development of the upper airway associated with higher prevalence of atopy in younger children probably explains this change [57]. Confirmation of these recent findings in a clinical research setting has been poor, even though a study conducted by Ulualp et al. [58] among patients 4 to 11 years of age with combined chronic OME and elevated numbers of adenoid mast cells using tympanometry showed a flat pattern with no apparent change in compliance of all diseased ears, although it was within normal limits in patients with isolated chronic adenoiditis with no appearance of atopy. Our previous study, conducted in children suffering from OME aged 5 to 6 years with the aim of evaluating the role of atopy in children attending primary school in Western Sicily and focusing on the audiological characteristics among atopic and nonatopic individuals suffering from OME, showed a statistically significant predominance of $\mathrm{B}$ tympanograms in atopic children $(79.1 \%)$ compared with nonatopic children (56\%) and with an OME population (70.59\%). The study of 
Table 1 Published studies reporting audiological measurements in children with otitis media and atopy

\begin{tabular}{|c|c|c|c|c|}
\hline Study & Year & Study design & Sample $^{\mathrm{a}}$ & Outcome \\
\hline $\begin{array}{l}\text { Ulualp } \\
\text { et al. [58] }\end{array}$ & 1999 & $\begin{array}{l}\text { Role of adenoid } \\
\text { mast cells in the } \\
\text { pathogenesis of } \\
\text { OME }\end{array}$ & $\begin{array}{l}\text { Istanbul, Turkey; } \\
40 \text { children aged } \\
4-11 \text { y }\end{array}$ & $\begin{array}{l}\text { Tympanic membrane opaque and mildly retracted in } \\
100 \% \text { of children with elevated number of adenoid } \\
\text { mast cells; flat pattern in } 100 \% \text { of tympanometry; pure } \\
\text { tone audiometry abnormal in } 100 \% \text { with a significant } \\
\text { difference between the children with adenoid mast cell } \\
\text { count below mean and patients with adenoid mast cell } \\
\text { count above mean }(P<0.05)\end{array}$ \\
\hline $\begin{array}{l}\text { Sente } \\
\text { et al. [56] }\end{array}$ & 2001 & $\begin{array}{l}\text { Incidence of allergic } \\
\text { rhinitis in cases of } \\
\text { eustachian tube } \\
\text { dysfunction }\end{array}$ & $\begin{array}{l}\text { Subotica, Croatia; } \\
200 \text { individuals aged } \\
5-19 \text { y }(80 \% \text { ranged } \\
\text { in age from } 5-9 \text { y) }\end{array}$ & $\begin{array}{l}26 \% \text { of individuals with eustachian tube dysfunction } \\
\text { suffered from allergic rhinitis; } 86.5 \% \text { type B } \\
\text { tympanogram; } 13.5 \% \text { C curve }\end{array}$ \\
\hline $\begin{array}{r}\text { Modrzyński } \\
\text { et al. [43] }\end{array}$ & 2003 & $\begin{array}{l}\text { Results of } \\
\text { tympanometry in } \\
\text { children with adenoid } \\
\text { hypertrophy and } \\
\text { coexisting allergy }\end{array}$ & $\begin{array}{l}\text { Grudziadz, Poland; } \\
89 \text { children aged } \\
4-10 \text { y }\end{array}$ & $\begin{array}{l}40.5 \% \text { of children with secretory otitis had positive skin } \\
\text { tests; } 72 \% \text { of atopic children presented with type B } \\
\text { tympanogram }(19 \% \text { type } \mathrm{C}) ; 21 \% \text { of nonatopic children } \\
\text { presented with type B tympanogram ( } 70 \% \text { type C) }\end{array}$ \\
\hline $\begin{array}{r}\text { Lazo-Sàenz } \\
\text { et al. [55] }\end{array}$ & 2005 & $\begin{array}{l}\text { Evaluation of eustachian } \\
\text { tube dysfunction in } \\
\text { allergic rhinitis } \\
\text { by tympanometry }\end{array}$ & $\begin{array}{l}\text { Torreòn, Mexico; } 57 \\
\text { children; mean age, } \\
8.8 \pm 4.2 \text { y for } \\
\text { allergic patients and } \\
7.11 \pm 4.0 \text { y for controls }\end{array}$ & $\begin{array}{l}\text { Abnormal curves in } 15.5 \% \text { of cases }(13 \% \mathrm{C} \text { curves, } 3 \% \mathrm{~B} \\
\text { curves); normal curves in } 100 \% \text { of controls }(P=0.03) \text {; } \\
\text { mean value for tympanometric peak pressure: cases, } \\
-54 \pm 66.2 \mathrm{daPa} \text {; controls, }-6.17 \pm 9.44 \mathrm{daPa} \text {, with } \\
\text { significant tympanometric abnormalities among the } \\
\text { groups }(P<0.05)\end{array}$ \\
\hline $\begin{array}{l}\text { Yeo } \\
\text { et al. [45] }\end{array}$ & 2007 & $\begin{array}{l}\text { Role of allergic rhinitis } \\
\text { in the development } \\
\text { of OME }\end{array}$ & $\begin{array}{l}\text { Seoul, South Korea; } \\
264 \text { children aged } \\
0.9-15 \text { y }\end{array}$ & $\begin{array}{l}6.3 \% \text { of atopic individuals ( } 4 \text { of } 63 \text { cases) had abnormal } \\
\text { tympanometric curves, compared with } 3.8 \% \text { of controls } \\
\text { ( } 3 \text { of } 79 \text { controls) }\end{array}$ \\
\hline $\begin{array}{l}\text { Leo } \\
\text { et al. [57] }\end{array}$ & 2008 & $\begin{array}{l}\text { Tympanometric alterations } \\
\text { in children with chronic } \\
\text { sinusitis and positive or } \\
\text { negative skin tests }\end{array}$ & $\begin{array}{l}\text { Milan, Italy; } 288 \\
\text { children aged } \\
\text { 1.9-14 y }\end{array}$ & $\begin{array}{l}76.4 \% \text { ( } 220 \text { of } 288 \text { ) of children with chronic sinusitis presented } \\
\text { with altered pressure of middle ear, with a higher prevalence } \\
\text { among younger children }(P<0.001) \text {; skin prick test positive } \\
\text { in } 29.9 \% \text { of these }(P=0.01) \text {; altered tympanogram in } 100 \% \\
\text { of atopic individuals aged }<3 \text { y, in } 74.3 \% \text { aged } 3-6 \mathrm{y} \text {, and in } \\
46.7 \% \text { aged }>6 \text { y }\end{array}$ \\
\hline $\begin{array}{l}\text { Martines } \\
\text { et al. [59••] }\end{array}$ & 2010 & Role of atopy in OME & $\begin{array}{l}\text { Western Sicily, Italy; } \\
310 \text { children aged } \\
5-6 \text { y }\end{array}$ & $\begin{array}{l}\text { OME prevalence rate, } 42.85 \% \text { for atopic individuals and } \\
6.3 \% \text { for nonatopic individuals }(P<0.001) \text {; OME bilateral in } \\
79.2 \% \text { of atopic and } 56.3 \% \text { of nonatopic individuals; } \mathrm{B} \\
\text { tympanogram in } 70.6 \%, 79.1 \% \text { for atopic and } 56 \% \text { for } \\
\text { nonatopic individuals }(P=0.04) \text {; mean air conduction pure } \\
\text { tone of } 31.97 \mathrm{~dB} \text { for atopic and } 29.8 \mathrm{~dB} \text { for nonatopic } \\
\text { individuals }(r=0.99 ; P<0.001)\end{array}$ \\
\hline $\begin{array}{l}\text { Martines } \\
\text { et al. [48••] }\end{array}$ & 2011 & $\begin{array}{l}\text { Statistical study of } \\
\text { audiological findings } \\
\text { in OME children with } \\
\text { or without atopy }\end{array}$ & $\begin{array}{l}\text { Western Sicily, Italy; } \\
123 \text { children aged } \\
5-6 \text { y }\end{array}$ & $\begin{array}{l}\text { ANOVA test for ear canal volume }(P<0.05) \text { : OME population } \\
0.65 \pm 0.38 \mathrm{~mL}, 0.59 \pm 0.37 \mathrm{~mL} \text { for B tympanogram, } \\
0.79 \pm 0.36 \mathrm{~mL} \text { for } \mathrm{C} \text { tympanogram; atopic individuals, } \\
0.64 \pm 0.38 \mathrm{~mL}, 0.6 \pm 0.38 \mathrm{~mL} \text { for B tympanogram, } \\
0.78 \pm 0.37 \mathrm{~mL} \text { for } \mathrm{C} \text { tympanogram; nonatopic individuals, } \\
0.66 \pm 0.37 \mathrm{~mL}, 0.56 \pm 0.35 \mathrm{~mL} \text { for B tympanogram, } \\
0.80 \pm 0.37 \mathrm{~mL} \text { for } \mathrm{C} \text { tympanogram; ANOVA test for } \\
\text { tympanometric peak pressure }(P<0.05) \text { : OME population, } \\
-251.75 \pm 112.24 \mathrm{daPa} \text {; atopic individuals, }-312.11 \pm 85.49 \\
\text { daPa; nonatopic individuals, }-202.36 \pm 110.12 ; \text { ANOVA test } \\
\text { for static compliance }(P<0.05): \text { OME population, } \\
0.59 \pm 0.23 \mathrm{~mL} \text {; atopic individuals, } 0.51 \pm 0.12 \mathrm{~mL} \text {; } \\
\text { nonatopic individuals, } 0.65 \pm 0.28 \mathrm{~mL}\end{array}$ \\
\hline
\end{tabular}

\footnotetext{
${ }^{a}$ All studies listed were case-control studies

ANOVA analysis of variance; $d a P A$ decaPascal; $O M E$ otitis media with effusion
}

tympanometric measurements has revealed significant differences among the considered groups $(P<0.05)$. Ear canal volume resulted in all cases being within normal range (0.4 $1.0 \mathrm{~mL}$ ), but lower values were seen in atopic children (mean value, $0.64 \pm 0.38 \mathrm{~mL}$ ) with respect to nonatopic individuals and to the total OME population $(0.66 \pm 0.37 \mathrm{~mL}$ for nonatopic individuals and $0.65 \pm 0.38 \mathrm{~mL}$ for the $\mathrm{OME}$ population). The evaluation of TTP and of static compliance 
(SC) among the OME population with $\mathrm{C}$ tympanogram also demonstrated that lower average values of TTP and SC were found in atopic children $(P<0.05)$. In particular, among the atopic population, the TTP average result was $-312.11 \pm 85.49$ $\mathrm{daPa}$ and the SC mean value was $0.51 \pm 0.12 \mathrm{~mL}$, while for nonatopic OME sufferers, the TTP average was $-202.36 \pm$ 110.12 , and the SC mean value was $0.65 \pm 0.28 \mathrm{~mL}$ [59••].

\section{Audiometric Measurements}

As stated above, conductive hearing loss in $\mathrm{OM}$ results from the attenuation of sound reaching the inner ear, usually consisting of 20 to $30 \mathrm{~dB}$, even if the degree of loss varies depending on character and quantity of effusion [60]. Ulualp et al. [58] conducted a study in children 4 to 11 years of age who suffered from chronic adenoiditis, with the aim of evaluating the possible relationship between atopy-adenoid mast cells and OME and/or hearing loss. The patients were divided into two groups-OME-A (chronic OME and chronic adenoiditis) and isolated chronic adenoiditis - and underwent pure tone audiometry and adenoidectomy. In addition, adenoid mast cells were counted in each specimen. By comparing the adenoid mast cells of the two groups, the number of adenoid mast cells in the OME-A group (median, 80) was found to be significantly greater than that in the isolated chronic adenoiditis group (median, 38; $P<0.05)$, confirming the contribution of atopy to the pathogenesis of OME. By comparing the hearing thresholds of the groups, it was shown that all isolated chronic adenoiditis patients had a normal hearing threshold, while those in the OME-A group had hearing thresholds ranging from 12 to $52 \mathrm{~dB}$. Moreover, the possible relationship of adenoid mast cells to hearing thresholds in OME-A patients was evaluated by comparing the hearing thresholds of OME-A patients with a mast cell count above the mean of OME-A group, and hearing thresholds of OME-A patients with a mast cell count below the mean of OME-A group. The authors found that OME-A patients with an adenoid mast cell count above the mean of the OME-A group had significantly higher hearing thresholds compared with OME-A patients with a mast cell count below the mean of OME-A group ( $33 \pm 2 \mathrm{~dB}$ and $24 \pm 2 \mathrm{~dB}$, respectively; $P<$ $0.05)$, with a correlation coefficient $r$ of $0.44(P=0.004)$ [58].

In our report, the mean air conduction pure tone was $29.8 \mathrm{~dB}$ for nonatopic individuals and $31.97 \mathrm{~dB}$ for atopic children, with an index correlation $r$ of $0.99(P<0.0001)$. In both groups, hearing sensitivity ranged from slight hearing loss $(20-40 \mathrm{~dB})$ to moderate hearing loss $(40-70 \mathrm{~dB})$, but $75 \%$ of cases with moderate hearing loss were atopic (three of four children). The correlation between atopy and a hearing dysfunction resulted de facto from the evidence that the worst hearing threshold level of $55 \mathrm{~dB}$, extremely rare in individuals with OME, was found in a patient with positive skin test; finally, there was evidence of a statistically significant difference in predominance of bilateral OME in atopic individuals $(79.2 \%)$ compared with nonatopic individuals $(56.3 \%)$ and with the total OME population $(70 \%)$. From the regression analysis, in fact, it was found that the relative risk for bilateral $\mathrm{OME}$ increases significantly in the presence of atopy $(r=0.99 ; P=0.005)[59 \bullet \bullet$.

\section{Otoscopic Examination}

Data in the literature are lacking with regard to otoscopic findings for both the general population and for atopic children suffering from OM. Otoscopic examination of patients with combined chronic OME and an elevated number of adenoid mast cells, as mentioned by Ulualp et al. [58], revealed that $97.5 \%$ of tympanic membranes were opaque and mildly retracted, while patients with isolated chronic adenoiditis have gray, translucent, and mobile tympanic membranes. From these observations, the question naturally arises of whether the otoscopic findings and the $\mathrm{OM}$ sequelae in atopic individuals are different from those among the general OM population?

Since $\mathrm{Li}$ et al. [61] found that repeated OM represents one of the clinical predictors of tympanic membrane retraction, as in atopic children, perennial allergic inflammation causes persistent blockage and dysfunction of the eustachian tube and thus repeated inflammations of the middle ear, it may be assumed that atopic children suffering from $\mathrm{OM}$ should present with a greater prevalence of persistent retraction than nonatopic OM sufferers. Also, for the tympanosclerosis, intended as OM sequelae, it may be possible to make some observations; in fact, to illuminate the correlation of inflammatory mediators in $\mathrm{OM}$ and tympanosclerosis development, Flodin and Hultcrantz [62] investigated the inflammatory parameters in an animal model after inoculation of $S$. pneumoniae into the middle ear, as well as in children suffering from secretory OM and in patients with already established tympanosclerosis. Results showed the presence of macrophages, $T$ cells, and B cells, and increased expression of IL-6 in rats after AOM induction, as well as in human biopsies. In particular, IL-6 expression was shown in a higher percentage of biopsies of children suffering from OM during its active phase [62]. As it is universally accepted, IL-6 represents one of the principal allergic mediators, and, consequently, it is an atopic component of $\mathrm{OM}$ and could induce in time to a clinical stage known as tympanosclerosis

\section{Conclusions}

Data in the literature data seem to support the hypothesis that allergic inflammation plays a role indirectly in the genesis and 
recurrence of $\mathrm{OM}$ by causing a persistent blockage of the eustachian tube or directly by means of middle ear mucosa inflammation. Several studies have shown a predominance of eosinophils, T lymphocytes, and Th2 mediators in the MEE, providing evidence that the inflammation within the middle ear of OM patients is allergic in nature. Moreover, in recent years, there has been increasing interest in the role played by the adenoids. Studies have suggested that adenoids may represent a potential site of allergic inflammation that can have an effect on eustachian tube function through the release of chemical mediators and concomitant hypertrophy, providing a further link between allergy and middle ear disease. The role of atopy in the development and persistence of $\mathrm{OM}$ is supported by different audiological characteristics between atopic and nonatopic individuals. Several studies have shown that the entity of OM seems to be different from OM caused by tubal dysfunction secondary to allergic inflammation. In fact, data have shown significant differences in active tubal function, in hearing acuity, and in the frequency of tympanic membrane changes, with a predominance of altered tympanograms and greater hearing loss in atopic children as compared with nonatopic children. However, very few studies have dealt with otoscopic examination in atopic individuals, so further studies are needed in this area.

Disclosure No potential conflicts of interest relevant to this article were reported.

\section{References}

Papers of particular interest, published recently, have been highlighted as:

- Of importance

-• Of major importance

1. Williamson I. Otitis media with effusion. Clin Evid. 2002;7:469-76.

2. Kubba H, Pearson JP, Birchall JP. The etiology of otitis media with effusion: a review. Clin Otolaryngol Allied Sci. 2000;25 (3):181-94.

3. Saim A, Saim L, Saim S, Ruszymah BHI, Sani A. Prevalence of otitis media with effusion among pre-school children in Malaysia. Int J Pediatr Otorhinolaryngol. 1997;41:21-8.

4. Takata GS, Chan LS, Morphew T, Mangione-Smith R, Morton SC, Shekelle P. Evidence assessment of the accuracy of methods of diagnosing middle ear effusion in children with otitis media with effusion. Pediatrics. 2003;112:1379-87.

5. Rovers MM, Schilder AGM, Zielhuis GA, Rosenfeld RM. Otitis media. Lancet. 2004;363:465-73.

6. Paradise JL, Rockette HE, Colborn DK, Bernard BS, Smith CG, Kurs-Lasky M, et al. Otitis media in 2253 Pittsburgh-area infants: prevalence and risk factors during the first two years of life. Pediatrics. 1997;99(3):318-33.

7. Casselbrant ML, Mandel EM. Epidemiology. In: Rosenfeld RM, Bluestone CD, editors. Evidence-based otitis media. 2nd ed. Hamilton: BC Decker; 2003. p. 147-62.
8. De Ru JA, Grote JJ. Otitis media with effusion: disease or defense? A review of the literature. Int J Pediatr Otorhinolaryngol. 2004;68:331-9.

9. Zielhuis GA, Rach GH, Den Bosch V, Den Broek V. The prevalence of otitis media with effusion: a critical review of the literature. Clin Otolaryngol. 1990;15:283-8.

10. Okur E, Yildirim I, Kilic MA, Guzelsoy S. Prevalence of otitis media with effusion among primary school children in Kahramanmaras, in Turkey. Int J Pediatr Otorhinolaryngol. 2004;68 (5):557-62.

11. - Martines F, Bentivegna D, Di Piazza F, Martinciglio G, Sciacca $\mathrm{V}$, Martines E. The point prevalence of otitis media with effusion among primary school children in Western children. Eur Arch Otorhinolaryngol. 2010;267(5):709-14. This article describes the prevalence of OME among children in the Mediterranean area, comparing the results with other countries. Moreover, this article evidences how atopy could represent one of the most important risk factors for otitis, especially in Sicily, where its action can be improved by weather (high humidity).

12. Schilder G, Zielhuis GA, Van Den Broek P. The otological profile of a cohort of Dutch 7.5-8-year-olds. Clin Otolaryngol. 1993;18(1):48-54.

13. El-Sayed Y, Zakzouk S. Point prevalence of type B tympanogram in Riyadh. Int J Pediatr Otorhinolaryngol. 1995;31(1):53-61.

14. Apostolopoulos K, Xenelis J, Tzagaroulakis A, Kandiloros D, Yiotakis J, Papafragou K. The point prevalence of otitis media with effusion among school children in Greece. Int $\mathrm{J}$ Pediatr Otorhinolaryngol. 1998;44(3):207-14.

15. • Daly KA, Hoffman HJ, Kvaerner KJ, Kvestad E, Casselbrant ML, Homoe P, et al. Epidemiology, natural history, and risk factors: panel report from the Ninth International Research Conference on Otitis Media. Int J Pediatr Otorhinolaryngol. 2011;74(3):231-40. This is a report from an international conference that identified in atopy one of the main factors in OM development.

16. Lim DJ, Chun YM, Lee HY, et al. Cell biology of tubotympanum in relation to pathogenesis of otitis media: a review. Vaccine. 2000;19 suppl 1:S17-25.

17. Bluestone $\mathrm{CD}$. Eustachian tube function and dysfunction. In: Rosenfeld RM, Bluestone CD, editors. Evidence-based otitis media. Hamilton: BC Decker; 1999. p. 137-56.

18. Bluestone CD. Pathogenesis of otitis media: role of eustachian tube. Pediatr Infect Dis J. 1996;15:281-91.

19. U.S. Department of Health and Human Services, Chapter 28: Vision and hearing. In Healthy People 2010 Midcourse Review, U.S. Government Printing Office, Washington, DC, 2006, 28-5.

20. Fireman P. Therapeutic approaches to allergic rhinitis: treating the child. J Allergy Clin Immunol. 2000;105:616-21.

21. Proets AW. Allergy in middle ear and internal ear. Ann Otol. 1931;40-61.

22. Koch H. Allergical investigations of chronic otitis. Acta Otolaryngol Suppl. 1947;(suppl.62):1-202.

23. Shambaugh Jr G. Pathology and clinical course of inflammatory diseases of the middle ear. In: Shambaugh Jr G, editor. Surgery of the ear. Philadelphia: W.B. Saunders Co.; 1967. p. 271-2.

24. Wright ED, Miotto D, Giguere C, Hamid Q. Increased expression of major basic protein (MBP) and interleukin-5(IL-5) in middle ear biopsy specimens from atopic patients with persistent otitis media with effusion. Otolaryngol Head Neck Surg. 2000;123:533-8.

25. Hurst DS, Venge P. Evidence of eosinophil, neutrophil, and mastcell mediators in the effusion of OME patients with and without atopy. Allergy. 2000;55:435-41.

26. Nagamine H, Iino Y, Kojima C, Miyazawa T, Iida T. Clinical characteristics of so called eosinophilic otitis media. Auris Nasus Larynx. 2002;29:19-28.

27. Jang $\mathrm{CH}$, Kim YH: Characterization of cytokines present in pediatric otitis media with effusion: comparison of allergy positive and negative. Int J Pediatr Otorhinolaryngol. 2002;37-40. 
28. Sobol SE, Taha R, Schloss MD, Mazer BD, Manoukian JJ, Tewfik TL, et al. TH2 cytokine expression in atopic children with otitis media with effusion. J Allergy Clin Immunol. 2002;110:125-30.

29. Nguyen LHP, Manoukian JJ, Sobol SE, Tewfik TL, Mazer BD, Schloss MD, et al. Similar allergic inflammation in the middle ear and the upper airway: evidence linking otitis media with effusion to the united airways concept. J Allergy Clin Immunol. 2004;114:1110-5.

30. • Caruso G, Damiani V, Salerni L, Passali FM: Atopy: pediatric ENT manifestations in children. Int J Pediatr Otorhinolaryngol 2009;S19 S25. There is a small section in this article dedicated to otitis.

31. •- Marseglia GL, Poddighe D, Caimmi D, Marseglia A, Caimmi S, Ciprandi G, et al. Role of adenoids and adenoiditis in children with allergy and otitis media. Curr Allergy Asthma Rep. 2009;9:460-4. This article indirectly describes the joint effect of allergy, adenoids, and URTIs in children suffering from otitis.

32. Marseglia GL, Pagella F, Caimmi D, Caimmi S, Castellazzi AM, Poddighe D, et al. Increased risk of otitis media with effusion in allergic children presenting with adenoiditis. Otolaryngol Head Neck Surg. 2008;138:572-5.

33. Dohlman FG. Allergiska processer i mellanorat. Nord Med Tidskr. $1943 ; 17: 224-6$

34. Mao CY. Allergy as a contributing factor to biologic deafness. Arch Otolaryngol. 1942;35:582-6.

35. Jordan R. Chronic secretory otitis media. Laryngoscope. 1949;59:1002-15.

36. Solow IA. Is serous otitis media due to allergy or infection? Ann Allergy. 1958;16:297-9.

37. Lecks HL. Allergic aspects of serous otitis media in childhood. NY State J Med. 1961;61:2737-43.

38. Fernandez AA, McGovern JP. Secretory otitis media in allergic infants and children. S Med J. 1965;58:581-6.

39. Whitcomb NJ. Allergy therapy in serous otitis media associated with allergic rhinitis. Ann Allergy. 1965;23:232-6.

40. Draper WL. Secretory otitis media in children: a study of 540 children. Laryngoscope. 1967;77:636-57.

41. Hall LJ, Asuncion J, Lukat M. Allergy skin testing under general anesthesia with treatment response in 92 patients with chronic serous otitis media. Am J Otol. 1980;2:150-6.

42. McMahan JT, Calenoff E, Croft DJ, Barenholtz L, Weber LD. Chronic otitis media with effusion and allergy: modified RAST analysis of 119 cases. Otolaryngol Head Neck Surg. 1981;89:427-31.

43. Modrzyński M, Zawisza E, Królikiewicz J. The results of tympanometry in children with adenoid hypertrophy and coexisting allergy. Przegl Lek. 2003;60(10):630-2.

44. Nsouli TM, Nsouli SM, Linde RE, Scanlon RT, Bellanti JA. The role of food allergy in serous otitis media. Ann Allergy. 1994;3(3):215-9.

45. Yeo SG, Park DC, Eun YG, Cha CI. The role of allergic rhinitis in the development of otitis media with effusion: effect on eustachian tube function. Am J Otolaryngol. 2007;28:148-52.

46. Hurst DS, Amin K, Seveus L, Venge P. Mast cells and tryptase in the middle ear of children with otitis media with effusion. Int $\mathrm{J}$ Pediatr Otorhinolaryngol. 1999;49:315-9.

47. Alles R, Parikh A, Hawk L, et al. The prevalence of atopic disorders in children with chronic otitis media with effusion. Pediatr Allergy Immunol. 2001;12:102-6.

48. • Martines F, Bentivegna D, Maira E, Sciacca V, Martines E: Risk factors for otitis media with effusion: case-control study in Sicilian schoolchildren. Int J Pediatr Otorhinolaryngol 2011, In press. This report compares all the possible risk factors for OME. There is a statistical study regarding each risk factor. Atopy is studied alone and together with other risk factors via analysis of variance (ANOVA) test of the joint effect of atopy with snoring, adenoids, URTI, and breastfeeding.

49. •• Martines F, Martinciglio G, Martines E, Bentivegna D. The role of atopy in otitis media with effusion among primary school children: audiological investigation. Eur Arch Otorhinolaryngol. 2010;267:1673-8. A study of audiometry threshold and tympanograms was performed among children with otitis evidencing the differences between atopic and nonatopic individuals. This study is mentioned in Table 1.

50. Rosenfeld RM, Culpepper L, Doyle KJ, Grundfast KM, Hoberman A, Kenna MA, et al. Clinical practice guideline: otitis media with effusion. Otolaryngol Head Neck Surg. 2004;130(May (5 Suppl)): S95-S118.

51. Kaleida PH, Fireman P. Diagnostic assessment of otitis media. Clin Allergy Immunol. 2000;15:247-62.

52. Recent advances in otitis media. Report of the Eighth Research Conference. June 3-7,2003. Fort Lauderdale, Florida, USA. Ann Otol Rhinol Laryngol Suppl 2005;194:6-160.

53. Fria TJ, Cantekin EI, Eichler JA. Hearing acuity of children with otitis media with effusion. Arch Otolaryngol. 1985;111:10-6.

54. - Ungkanont K, Charuluxananan S, Komoltri C. Association of otoscopic findings and hearing level in pediatric patients with otitis media with effusion. Int $\mathrm{J}$ Pediatr Otorhinolaryngol. 2010;74:1063-6. This represents a starting point for a study of audiometric threshold in individuals suffering from $O M$.

55. Lazo-Saenz JG, Galvan-Aguilera AA, Martinez-Ordaz VA, Velasco-Rodriguez VM, Nieves-Renteria A, Rincon-Castaneda C. Eustachian tube dysfunction in allergic rhinitis. Otolaryngol Head Neck Surg. 2005;132:626-31.

56. Sente M, Sente R, Puleva K, et al. Allergic rhinitis as a possible etiologic cause eustachian tube dysfunction. Med Pregl. 2001;54 (3-4):166-71.

57. Leo G, Piacentini E, Incorvaia C, Consonni D, Cazzavillan A. Prevalence of tympanometric alteration in children with chronic sinusitis. Int J Pediatr Otorhinolaryngol. 2008;72:315-9.

58. Ulualp SO, Sahin D, Yilmaz N, Anadol V, Peker O, Gursan O. Increased adenoid mast cells in patients with otitis media with effusion. Int J Pediatr Otorhinolaryngol. 1999;49:107-14.

59. •• Martines F, Martines E, Sciacca V, Bentivegna D. Otitis media with effusion with or without atopy: audiological findings on primary school children. Am J Otolaryngol 2010 Dec 3. doi:10.1016/j.amjoto.2010.08.002. ANOVA test for all the tympanometric measurements was performed. In particular, it compared ear canal volume, TPP, and SC for an atopic and a nonatopic population. The results are described in a section inside the article and reported in Table 1.

60. Madell JR. Impact of Otitis Media on auditory function. In: Rosenfeld RM, Bluestone CD, editors. Evidence-based Otitis Media. Hamilton: B. C. Decker; 1999. p. 337-52.

61. Li Y, Hunter LL, Margolis RH, Levine SC, Lindgren B, Daly K, et al. Prospective study of tympanic membrane retraction, hearing loss, and multifrequency tympanometry. Otolaryngol Head Neck Surg. 1999;121(November (5)):514-22.

62. Flodin MF, Hultcrantz M. Possible inflammatory mediators in tympanosclerosis development. Int J Pediatr Otorhinolaryngol. 2002;63:146-54. 